\title{
The Use of Legend in Tourism: Case Study of Si Pitung from Indonesia
}

\author{
Yostiani Noor Asmi Harini \\ Departemen Pendidikan Bahasa dan Sastra Indonesia \\ Universitas Pendidikan Indonesia \\ yostiani@upi.edu
}

\begin{abstract}
In around the world, legend has impacts on tourism. In Indonesia, there is a legend of Si Pitung. Si Pitung is an Indonesian hero (similar to Robin Hood in England). The house and the grave of $\mathrm{Si}$ Pitung become tourist destinations in Jakarta, Indonesia. The legend of Si Pitung has impacts on tourism in some ways. These impacts can be used to develop tourism. The aim of the article is to highlight the importance of the legend in tourism and its subsequent impact on development within the area, especially Jakarta.
\end{abstract}

Keywords: legend, si pitung, and tourism

\section{INTRODUCTION}

According to the legend, Pitung is a virtuous young man from Rawa Belong. Since his childhood, besides studying religion, he also learned martial arts from Haji Naipin, so he grew into a brave and noble person who used to defend weak people. At that time, kompeni (Dutch colonials), tauke, and landlords oppressed poor people by extorting them. Seeing this, Si Pitung did not remain silent. He and his friends robbed the property of the kompeni, the landlords and the tauke to be distributed to the poor. They were very grateful to Pitung, but the colonials, the tauke, and landlords were furious at him. They set to chase or kill Pitung. Unfortunately, they failed because of Pitung's tricks and divine power. Kompeni then found Pitung's weakness and finally he was successfully killed [1].

Pitung is one of popular Indonesian folklores. The story has been written into series of story books, such as Buku Seri Cerita Rakyat 34 Provinsi, Si Pitung [2], Si Pitung Superhero Betawi Asli [3], Si Pitung Pendekar Betawi [4], etc. In addition, there are also some movies about Pitung, like Si Pitung Banteng Betawi (1971), Si Pitung Beraksi Kembali (1976), and Pembalasan Si Pitung [5].

As a folklore, the legend of Si Pitung has many versions. According to the public, Pitung is a hero but according to the kompeni, he is a bad guy. Moreover, some people think that he is individual and others think he is a collective like Al-Fattah wrote in his book.

In the book Pitung (Pituan Pitulung): Jihad Fi Sabillah Para Pejuang Menyelamatkan Jayakarta, AlFattah wrote Pitung was not the name of a character but seven swordsmen. According to him, Pitung stands for Pituan Pitulung, which means the seven helpers. Pituan
Pitung is a popular resistance organization in Jayakarta (former Jakarta) which was established in 1880. This opinion is obtained from Al-Fatawi. [6]

The fame of the legend made the government of DKI Jakarta Province restore a stage house that is believed to be Pitung's house in Marunda as a cultural heritage in 1992. Around the house, there is also the tomb of Pitung as a place of pilgrimage. This study further discusses the impact of the legend existence on tourism and development, especially in Jakarta, Indonesia.

\section{METHOD}

This research is a case study research. I consider the existence of Si Pitung legend which later develops into a tourist destination and Si Pitung's tomb as a phenomenon. The source of research data was taken from various sources both oral and written. This study used descriptive qualitative method.

\section{RESULT}

Since the 1960s, the government has realized that tourism will increase income for the country [6]. Visiting the place while listening to Si Pitung story from the tour guide can be classified as cultural tourism because that is a packed tour. Yoety [7] stated that phenomenon is the commercialization of art and culture in tourism. For some people, commercialization of art and culture is frightening. However, if we are able to nurture and develop the nation's cultural identity, we have no worry about that. Cultural commercialization in other side can be seen as a new form of creation to preserve the culture, including preserving Si Pitung legend.

As a legend, Si Pitung's story lives as a tradition. As a tradition, this story has a pattern that makes the story easy to remember. Here are the main functions of $\mathrm{Si}$ Pitung's legend based on Todorov's theories.

F1: Exploitation of natural and human resources by the kompeni, the tauke, and the landlords

F2: Social gap between the kompeni, the tauke, the landlords and indigenous people

F3: Pitung's desire to help indigenous people

F4: Pitung's robbery of the kompeni, the tauke, and the landlords

F5: The anger of the kompeni, the tauke, and the landlords to Pitung

F6: Distributed property of the kompeni, the tauke, and the landlords to indigenous people by Pitung 
F7: The happines of indigenous people

F8: The desire of the kompeni, the tauke, and the landlords to kill Pitung

F9: Pitung's divine power (called Rawa Rontek)

F10: It is difficult to kill Si Pitung

F11: The efforts of the kompeni to find the weakness of Pitung

F12: The kumpeni found Pitung's weakness

F13: Si Pitung's death

Here is the main function chart of Si Pitung's legend. Chart 1 The Main Function of Si Pitung legend

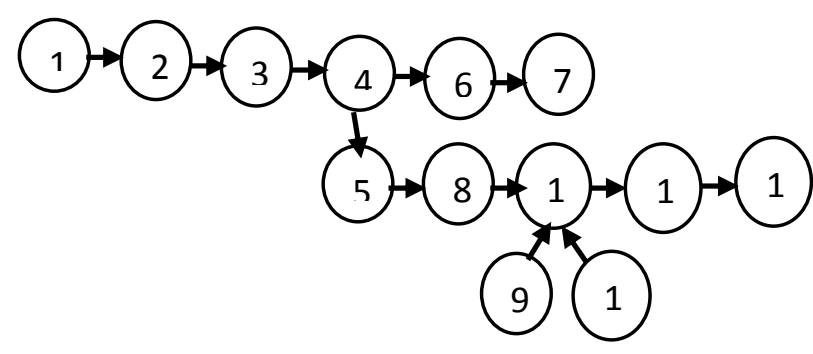

In chart 1 , a sequential primary function number appears in the main function of the next number. The sequence in this story is shown through Chart 2.

\section{Chart 2 The Sequence of Si Pitung legend}

\section{$\longrightarrow 13$}

The sequence in this story is linear. The sequence which is almost the same as the main function is typical patterns found in oral folklore. This happens because in the oral tradition, the speaker tries to make it easier to remember. This is in accordance with Ong's opinion (2013) that in an oral tradition there are patterns. [8]

The results showed that the legend of Si Pitung can be classified into individual legend. Individual legend is a story about certain characters who are considered by the owner of the story to happen [9]. The owner of the story within the context of legend of Si Pitung is Betawi society, Indonesia. Therefore, the setting of place and time in the legend is closely related to the life of Betawi people. The background places that appear in the legend are the house and the tomb. Here are photos of $S i$ Pitung's house and tomb.
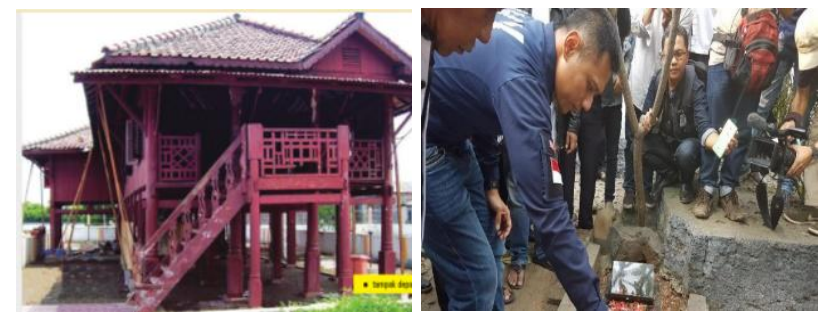

$\begin{array}{lll}\text { Picture 1. Si Pitung's } & \begin{array}{l}\text { Picture 2. Pilgrimage to Si } \\ \text { Pitung's Tomb [11] }\end{array} \\ \text { House [10] } & & \text { Tomb }\end{array}$

As tourist destinations, Pitung's house and tomb are open for public. Visitors can visit the place while enjoying Si Pitung's story from the tour guide. Through these activities, the legacy of the legend of Si Pitung occurred. Inheritance of the legend by telling the legend at the scene of events will bring speakers and speakers to feel the context in the story. Thus, the legendary inheritance will occur on an ongoing basis. The existence of this tourism destination makes the legend of Si Pitung will continue to live. In addition to economic terms (with a ticket that can supplement local revenue), the existence of this tourism destination participates in developing the character of the nation.

The existence of Si Pitung legend can be seen as a community projection system. In conditions of hardship, people want the presence of a hero who will save them. With the hero, the difficulties faced will be lighter. In the story, Si Pitung emerged as the ideal heroic figure in the community. He was very kind. He could not keep silent when injustice occurred, always defended the community, and even would sacrifice his life. This differs greatly from the description of the many-imaged leaders in the mass media who seem more self-interested than the public interest.

The admission of this tourism destination is only five thousand rupiahs for adults and one thousand five hundred rupiahs for children. By the cheap price, it shows that the economic aspect is not the priority for the business. The priority is the legend's inheritance because it can be used as an educational facility.

When the house of Si Pitung is used as a place of cultural preservation and tourism destination, some people believe Si Pitung came from Marunda and Rawa Belong. After further exploration, the house belonged to Safiuddin, a landlord from Bugis whose house was robbed by the Group of Seven/Si Pitung [12], [13]. This phenomenon can increase curiosity about the legend of $S i$ Pitung deeper.

The existence of $S$ Pitung's house as educational facility because it is a traditional Betawi stage house. This house is usually for coastal, swamp, or river area. The construction is designed to avoid the threat of sea water. By looking at home typography, the children will be able to learn how society adapts to the environment.

In addition, in terms of characterizations, Si Pitung was told as someone who studied diligently. He was told as someone who had divine power and bulletproof. It made him a strong person and feared by his enemies. His divine power was called Rawa Rontek. The tomb of Si Pitung was not just one. This happened because it was told he possessed Rawa Rontek. Si Pitung was invincible until one of his friends betrayed him. His friend revealed Pitung's weakness to the kompeni. It said that the power would vanish when Si Pitung was pelted by rotten eggs. After being pelted by the rotten eggs, he could be killed by a golden bullet.

Another version said that Si Pitung was killed and his head and body were separated. This was the way to kill him. That is why there were two tombs of him. It was told that one of these tombs was Pitung"s headless body. From this story, people can take a lesson about the danger of betrayal. 
Beside for tourism, this legend is also for entertainment. Entertaining facilities can be obtained when the tour guide tells the story or the visitors enjoy the atmosphere around. They can also take pictures with friends to share their unforgettable memory.

\section{CONCLUSION}

Based on the explanation above, it can be concluded that the legend has an impact on tourism. The use of the legend in tourism does not only emphasize on economic factors, but also the continuity of legendary inheritance. Legend in tourism spots as well representing the projection system of society can be used as a medium of education and entertainment.

\section{REFERENCES}

[1] H. Erwantoro, dkk., Cerita Si Pitung: Tokoh Legendaris dalam Pandangan Masyarakat Betawi, Bandung: BPNB Bandung, 2012.

[2] D. Kristiani. Seri Cerita Rakyat 34 Provinsi: Si Pitung. Bandung: BIP, 2017.

[3] S.SA. Si Pitung; Superhero Betawi Asli. Bandung: DAR! Mizan, 2009.

[4] S. Hadi. Si Pitung Pendekar Betawi. Jakarta: Taufik, 2011.

[5] I. M. Al-Fattah. Pitung (Pituan Pitulung): Jihad Fi Sabillah Para Pejuang Menyelamatkan Jayakarta, Jakarta: Pustaka Al-Kautsar, 2017.
[6] Marsono, "Bahasa, Sastra, Seni, dan Budaya Jawa sebagai Aset Wisata". Pidato Pengukuhan Jabatan Guru Besar Fakultas Ilmu Budaya UGM, 2003.

[7] O. A.Yoety. Komersialisasi Seni Budaya dalam Pariwisata, Bandung: Angkasa, 1985.

[8] W. J. Ong. Kelisanan dan Keaksaraan. Yogyakarta: Gading Publishing, 2013.

[9] J. Danandjaja. Folklor Indonesia: Ilmu Gosip, Dongeng, dan Lain-lain. Jakarta: Pustaka Utama Grafiti, 2002.

[10] W. Adi. Batavia 1740: Menyisir Jejak Betawi, Jakarta: PT Gramedia Pustaka Utama, 2010.

[11] B. Adhes. "Kitab Al-Fatawi, Cerita Si Pitung Versi Iwan Mahmoed Al-Fattah". [Daring] orangbetawi.com.

http://www.orangbetawi.com/2017/12/kitab-alfatawi-cerita-si-pitung-versi-iwan-mahmoed-alfattah, 13 Desember 2017.

[12] D. Swadarma dan Y. Aryanto. Rumah Etnik Betawi, Jakarta: Griya Kreasi, 2013

[13] M. Y. Manurung. "Tokoh Betawi Tunjukan Kekeliruan Buku Pitung Versi Iwan Mahmoed" Tempo.co. [Daring] http://www.orangbetawi.com/2017/12/kitab-alfatawi-cerita-si-pitung-versi-iwan-mahmoed-alfattah. 